Original research article

\title{
Sunitinib malate inhibits hemangioma cell growth and migration by suppressing focal adhesion kinase signaling
}

\author{
Wihan Scholtz, Peace Mabeta * \\ University of Pretoria, Faculty of Health Sciences, Department of Physiology, Angiogenesis Laboratory, South Africa
}

\begin{abstract}
Sunitinib malate is a small molecule that targets multiple receptor tyrosine kinases and blocks their activity. Receptors targeted by sunitinib are implicated in tumor vascularization and are overexpressed by vascular tumors encountered in infants, namely, hemangiomas. Of note is that there is still no definitive treatment for these commonly occurring tumors of infancy. The purpose of this study was to investigate the effects of sunitinib malate on hemangioma using endothelial cells isolated from a murine model of the neoplasm (sEnd.2). The effects of the drug on cell growth were evaluated using the crystal violet assay and flow cytometry, while the scratch assay was employed to measure cell migration. Proteins associated with cell migration and angiogenesis were detected using western blotting. Sunitinib was investigated further to determine its effects on the production of reactive oxygen species, a parameter associated with the promotion of neovascularization in tumors. The results showed that sunitinib significantly reduced the growth of sEnd. 2 cells by causing the cells to accumulate in the sub-G1 phase of the cell cycle, and also induced a significant decrease in the migration of these hemangioma cells $(P<0.05)$. The western blot assay showed a decrease in the expression of adhesion proteins, focal adhesion kinase and paxillin at $\mathrm{IC}_{50}$ doses, although the expression of cadherin did not change significantly $(P<0.05)$. In addition, transforming growth factor- $\beta 1$ (TGF- $\beta 1$ ) expression was decreased in sunitinib-treated cells at the same dose. The adhesion proteins as well as TGF- $\beta 1$ regulate cell movement and have been implicated in tumor progression. Thus, sunitinib malate may have potential in the treatment of hemangiomas.
\end{abstract}

Keywords: Angiogenesis; Focal adhesion kinase; Hemangioma; Migration; Sunitinib

Highlights:

- The study shows for the first time the effectiveness of VEGFR blockers, MAZ-51 and sunitinib malate in suppressing hemangioma growth.

- Data further shows the MAZ-51 and sunitinib malate are more effective in benign rather than malignant skin tumor cells.

- The expression of adhesion and angiogenesis promoting proteins that enable tumor progression (FAK, paxillin, TGF- $\beta 1$ ) were suppressed by sunitinib malate.

\section{Introduction}

Hemangiomas are the most commonly diagnosed tumors in infants (Ionescu et al., 2008; Mabeta and Pepper, 2011). These endothelial cell neoplasms are characterized by abnormal and aggressive angiogenesis (Liu et al., 2013; Mabeta, 2018; Mabeta and Pepper, 2015). Angiogenesis, the formation of blood vessels from a pre-existing microvessels, is mediated by numerous factors which either stimulate or inhibit the process, otherwise referred to as positive and negative regulators of angiogenesis respectively (Weis and Cheresh, 2011). In hemangioma, positive regulators of angiogenesis predominate and constitutive vascular endothelial growth factor-A (VEGF-A) signalling plays a role in the development of hemangiomas (Chim et al., 2012; Mabeta, 2018; Park et al., 2020).
The main receptors for VEGF-A are vascular endothelial growth factor receptor-1 and -2 (VEGFR-1 and VEGFR-2) and both have been implicated in hemangiomagenesis (Mabeta, and Pepper, 2012; Podar and Anderson, 2011; Tugues et al., 2011). Another VEGF receptor, which binds vascular endothelial growth factor-C and -D (VEGF-C and VEGF-D), VEGFR-3, was detected in hemangioma tissue but not in adjacent normal tissue. In addition, studies have further suggested that mutations in the VEGFR-3 gene may contribute to the neoplasm (Ji et al., 2014; Walter et al., 2002). Of note is that these VEGF receptors are targeted by several small molecule inhibitors such as the VEGFR-3 inhibitor, Maz-51 and sunitinib malate (Braconi et al., 2008; Kirkin et al., 2004).

Sunitinib malate (N-(2-diethylaminoethyl)-5-[(Z)-(5-fluoro -2-oxo-1H-indol-3-ylidene)methyl]-2,4-dimethyl-1H-pyrrole3 -carboxamide) is a receptor tyrosine kinase inhibitor (RTKI)

\footnotetext{
* Corresponding author: Peace Mabeta, University of Pretoria, Faculty of Health Sciences, Department of Physiology, Angiogenesis Laboratory, P/Bag X323, Arcadia, 0007, South Africa; e-mail: peace.mabeta@up.ac.za http://doi.org/10.32725/jab.2020.019

Submitted: 2020-06-09 • Accepted: 2020-12-03 • Prepublished online: 2020-12-07

J Appl Biomed 18/4: 143-151 • EISSN 1214-0287 • ISSN 1214-021X

(c) 2020 The Authors. Published by University of South Bohemia in České Budějovice, Faculty of Health and Social Sciences.

This is an open access article under the CC BY-NC-ND license.
} 
approved by the Food and Drug administration (FDA) for the treatment of renal cell carcinoma (RCC) and gastrointestinal stromal tumors (GIST) that are resistant to imatinib (Braconi et al., 2008; Joseph et al., 2016). It exerts its mechanism of action by blocking VEGFR-1, -2, PDGFRs, FMS-like tyrosine kinase 3 (FLT-3) and the stem cell factor receptor c-KIT (Haas et al., 2016; Quintieri et al., 2014). Given that MAZ-51 and sunitinib block receptors implicated in hemangiomagenesis, the effects of these drugs on hemangioma cell growth were investigated. We further sought to elucidate the mechanism of action of VEGFR inhibition on hemangioma in vitro by studying cell migration, reactive oxygen species production as well as the expression of adhesion and angiogenic protein markers.

\section{Materials and methods}

\section{Cell culture}

The sEnd. 2 endothelial cell (EC) line was isolated from mouse cutaneous hemangiomas and was obtained from Prof. M.S. Pepper (University of Pretoria, South Africa). The B16-F10 is a malignant cutaneous melanoma cell line and it was purchased from the American Type Culture Collection (ATCC, MD, USA).

Both cell lines were cultured in Dulbecco's Modified Eagle's Medium (DMEM) (Whitehead Scientific, Johannesburg, SA) supplemented with $10 \%$ fetal bovine serum (FBS) (Sigma Aldrich, St. Louis, MO, USA) and 1\% penicillin-streptomycin (Sigma Aldrich, St. Louis, MO, USA) in a humidified incubator (NuAire, Plymouth, USA) at $37{ }^{\circ} \mathrm{C}$ and $5 \% \mathrm{CO}_{2}$.

\section{Cell viability assay}

Crystal violet, a stain that binds to deoxyribonucleic acid (DNA) in live cells was employed to study cell viability using a previously described protocol with slight modification (Feoktistova et al, 2016). The sEnd.2 and B16-F10 cells were seeded in 96 -well plates at a density of $5 \times 10^{3}$ per well and allowed to attach overnight. The cells were treated with either sunitinib $(0.1-10 \mu \mathrm{g} / \mathrm{ml})$, MAZ-51 $(0.1-10 \mu \mathrm{g} / \mathrm{ml})$ or $0.05 \%$ dimethyl sulfoxide (DMSO) for 24 hours at $37{ }^{\circ} \mathrm{C}$ and $5 \% \mathrm{CO}_{2}$ in a humidified incubator. MAZ-51 is an indolinone that inhibits the function of VEGFR-3 by blocking the ligand induced autophosphorylation of this receptor tyrosine kinase (Kirkin et al., 2004) while sunitinib is a multi-targeting tyrosine kinase inhibitor which blocks multiple VEGFRs. The drug concentrations and exposure time of sunitinib and MAZ-51 were chosen following initial screening.

At termination, the cells were fixed in $1 \%$ glutaraldehyde (GA) for $15 \mathrm{~min}$ at room temperature and then stained with $0.1 \%$ crystal violet (Sigma Aldrich, St. Louis, MO, USA) solution for $30 \mathrm{~min}$. The plates were washed under running water for $20 \mathrm{~min}$ and dried. Thereafter, $100 \mu \mathrm{l}$ of a $0.1 \%$ Triton $\mathrm{x}-100$ solution was added to each well and the cells were incubated at room temperature for $60 \mathrm{~min}$. The absorbance was measured at $570 \mathrm{~nm}$ using a BioTek ELx800 microplate reader (BioTek instruments Inc., VT, USA). Three wells were analyzed per treatment and experiments were conducted in triplicate. The half maximal inhibitory concentration $\left(\mathrm{IC}_{50}\right)$ of cell growth was calculated from data obtained from crystal violet assay results using GraphPad Prism 5 Software. The calculated IC $_{50}$ for sunitinib malate was $2.600 \mu \mathrm{g} / \mathrm{ml}(4.881 \mu \mathrm{M})$ for endothelial cells, and this concentration was employed for further investigation on the drug's mechanism of action.

\section{Cell cycle analysis}

For cell cycle analysis, the fluorescent nucleic acid dye propidium iodide (PI) was employed to stain cells. Endothelial
(sEnd.2) cells were seeded in T25 flasks at $1 \times 10^{6}$ cells $/ \mathrm{ml}$, and therefore 5 million cells were transferred to each flask. The cells were incubated for $24 \mathrm{~h}$ at $37{ }^{\circ} \mathrm{C}$ and $5 \% \mathrm{CO}_{2}$ in a humidified incubator. The cells were then treated with $2.6 \mu \mathrm{g} /$ $\mathrm{ml}$ ( $\mathrm{IC}_{50}$ dose) sunitinib and a positive control, nocodazole at $0.5 \mu \mathrm{g} / \mathrm{ml}$ for $24 \mathrm{~h}$ at $37^{\circ} \mathrm{C}$ and $5 \% \mathrm{CO}_{2}$ in a humidified incubator. The cells were harvested using trypsin, centrifuged at $400 \mathrm{rpm}(580 \times \mathrm{g})$ for 10 minutes and resuspended in DMEM. The cells were then counted and $1 \times 10^{6}$ cells were washed with PBS and centrifuged at $400 \mathrm{rpm}(580 \times \mathrm{g})$. The supernatant was removed, and the cells were fixed in $1 \mathrm{ml}$ cold $70 \%$ ethanol in $\mathrm{ddH}_{2} \mathrm{O}$. The ethanol was added dropwise to the pellet while vortexing to minimize aggregation and to ensure fixation of all cells. The samples were stored at $-20^{\circ} \mathrm{C}$ overnight. The samples were then centrifuged at $2000 \mathrm{rpm}(5800 \times \mathrm{g})$ and washed twice with PBS. The supernatant was removed and $50 \mu \mathrm{l}$ of $100 \mu \mathrm{g} / \mathrm{ml}$ RNase A in PBS were added directly to the pellet, followed by $400 \mu \mathrm{l}$ of $50 \mu \mathrm{g} / \mathrm{ml}$ PI in PBS and then vortexed. The cells were incubated for at least $10 \mathrm{~min}$ to stain in the dark before being analyzed using a Beckman FC 500 Series Flow $\mathrm{Cy}_{-}$ tometer (Beckman Coulter Life Sciences, CA, USA).

Propidium iodide fluorescence was detected on the FL3 channel (excitation/emission 496/633 nm). A minimum of 10000 events were analyzed for each treatment.

\section{Scratch migration assay}

To measure cell migration, the scratch assay was employed as previously described (Mabeta and Pepper, 2009). Briefly, cell culture dishes were precoated with $0.2 \%$ gelatin (Sigma Aldrich, St. Louis, MO, USA) and cells were seeded at $8 \times 10^{5}$ cells per culture dish overnight. Thereafter, a scratch was created in the center of the cell monolayer using a pipette tip followed by rinsing of cells with PBS. The cells were then treated with sunitinib $(2.6 \mu \mathrm{g} / \mathrm{ml})$ or $0.05 \%$ DMSO over $24 \mathrm{~h}$, and a series of images were captured at 0, 6, 20 and $24 \mathrm{~h}$ using a Zeiss Axiocam MRM camera mounted on a Zeiss Axiovert $40 \mathrm{CFL}$ (Carl Zeiss, Oberkochen, Germany).

\section{Western blot}

The sEnd. 2 cells were seeded at 200000 cells/well in 6-well plates and incubated for $24 \mathrm{~h}$ at $37^{\circ} \mathrm{C}$ and $5 \% \mathrm{CO}_{2}$ in a humidified incubator. The cells were treated with sunitinib at $\mathrm{IC}_{50}$ and double $\mathrm{IC}_{50}$ doses $(2.6 \mu \mathrm{g} / \mathrm{ml}$ and $5.2 \mu \mathrm{g} / \mathrm{ml}$ respectively) or $0.05 \%$ DMSO for $24 \mathrm{~h}$. At termination the cells were rinsed with cold $0.1 \mathrm{M}$ PBS and lysed in $200 \mu \mathrm{l}$ of RIPA (150 mM $\mathrm{NaCl}, 0.1 \%$ Triton $\mathrm{X}-100,0.5 \%$ sodium deoxycholate, $0.1 \%$ SDS, 50 mM Tris-HCl, pH 8.0) lysis buffer. Protein determination was performed using a bicinchoninic acid (BCA) assay kit (Thermo Fischer Scientific, Johannesburg, RSA) to standardize all samples to the same concentration. For analysis, $4 \%$ lithium dodecyl sulphate (LDS) buffer and 2.5\% Mercaptoethanol were added to the lysates.

The samples were incubated for 5 minutes at $80^{\circ} \mathrm{C}$ and centrifuged for 1 minute at $12000 \mathrm{RPM}$ and $21^{\circ} \mathrm{C}$. Samples were then loaded on the gel together with a protein ladder at $5 \mu \mathrm{l}$. Thereafter, MOPS (50 mM MOPS, $50 \mathrm{mM}$ Tris Base, $1 \mathrm{mM}$ EDTA, $0.1 \%$ SDS, pH 7.7) running buffer was used to run the gels at $120 \mathrm{~V}$ for $90 \mathrm{~min}$. Proteins were transferred overnight to a methanol-activated Polyvinylidene fluoride (PVDF) membrane at $90 \mathrm{~V}$ at $2{ }^{\circ} \mathrm{C}$. The membrane was blocked using $3 \%$ non-fat milk in $0.01 \mathrm{M} \mathrm{PBS}$ for $1 \mathrm{~h}$, followed by incubation with $5 \mu \mathrm{l}$ primary antibody in $5 \mathrm{ml}$ blocking buffer (TGF- $\beta 1: 1000$; FAK 1 : 1000; Cadherin $1: 1000)$ for $24 \mathrm{~h}$ at $2{ }^{\circ} \mathrm{C}$ on a roller. The membrane was washed three times with PBS-Tween for 5 min and incubated with the HRP-conjugated secondary antibody, goat IgG for $3 \mathrm{~h}$ and then washed with PBS-Tween. Detection 
was performed using Chemiluminesence Biorad Chemidoc MP System (Bio-Rad Laboratories Inc, California, USA), and the electro chemiluminescence (ECL) kit. Quantitative results were presented as the fold change (FC), which is the change in protein abundance relative to the control. Protein expression was normalized to actin.

\section{Oxidative stress assay}

Superoxide anion levels were measured using the Muse ${ }^{\circledR}$ Oxidative Stress Kit (Merck Millipore, MA, USA) according to the manufacturer's instructions. Briefly, sEnd.2 cells were seeded in T25 flasks at $1 \times 10^{6}$ cells $/ \mathrm{ml}$ and incubated overnight at $37^{\circ} \mathrm{C}$ and $5 \% \mathrm{CO}_{2}$ in a humidified incubator. Cells were treated with sunitinib $(2.6 \mu \mathrm{g} / \mathrm{ml})$ or $0.05 \%$ DMSO for $24 \mathrm{~h}$, harvested using trypsin, centrifuged at $400 \mathrm{rpm}(580 \times \mathrm{g})$ and resuspended in $1 \times$ assay buffer at $5 \times 10^{6}$ cells $/ \mathrm{ml}$.

The Muse ${ }^{\circledR}$ Oxidative Stress Reagent working solution was then added to samples and following a 30-min incubation at $37{ }^{\circ} \mathrm{C}$ samples were analyzed using the Muse ${ }^{\circledR}$ Cell Analyzer (Merck Millipore, MA, USA).

\section{Statistical analysis}

By convention sample size is chosen so that the residual degrees of freedom are at least 30 . To comply with the latter, six experiments were conducted i.e. six observations (mean of three replicates per experiment) per drug-concentration combination. In each of the experiments a negative control was also included. Data analysis employed an appropriate analysis of variance (ANOVA) with fixed effects, drugs and concentrations. Data summary was by drug and concentration mean and standard deviation (SD). Data analysis was conducted with the Stata Release 14.0 statistical software. The level of significance was designated at 0.05 .

\section{Results}

\section{Cell growth}

To determine the effects of sunitinib malate on cell growth, cell viability and cell cycle analysis were undertaken. Both cell viability and the cell life cycle are tightly linked to growth (Ignarro et al., 1987).

\section{Cell viability assay}

The drugs MAZ-51 and sunitinib were evaluated to determine possible effects on the viability of ECs derived from murine skin hemangiomas, the sEnd.2 cells. Another cell line which was derived from a malignant skin tumor, the melanoma B16-F10 cells, was also employed to study the effects of these drugs on cell viability. In sEnd. 2 cells, MAZ-51 had no significant effect at a dose of 0.1 and $1 \mu \mathrm{g} / \mathrm{ml}$, but decreased the percentage of viable cells to $48.902 \%$ only at $10 \mu \mathrm{g} / \mathrm{ml}$ (Fig. 1A). Sunitinib induced significant inhibition of sEnd.2 cells to $54.63 \%$ and $38.2 \%$ at doses of 1 and $10 \mu \mathrm{g} / \mathrm{ml}$, with an $\mathrm{IC}_{50}$ value of $2.600 \mu \mathrm{g} / \mathrm{ml}$. In melanoma cells, $0.1 \mu \mathrm{g} / \mathrm{ml}$ of MAZ-51 had no significant effect on cell survival. Nonetheless, MAZ51 reduced cell viability at concentrations of 1 and $10 \mu \mathrm{g} / \mathrm{ml}$ to $68.751 \%$ and $48.914 \%$ (Fig. 1B). Sunitinib decreased the percentage of viable melanoma cells to 77.628 and 45.628 at 1 and $10 \mu \mathrm{g} / \mathrm{ml}$ respectively (Fig. 1B). The effects of both drugs were more pronounced on sEnd. 2 cells. Sunitinib was more potent than MAZ-51 in inhibiting both endothelial and melanoma cell growth $(P<0.05)$ and thus, further studies were undertaken using sunitinib.

B

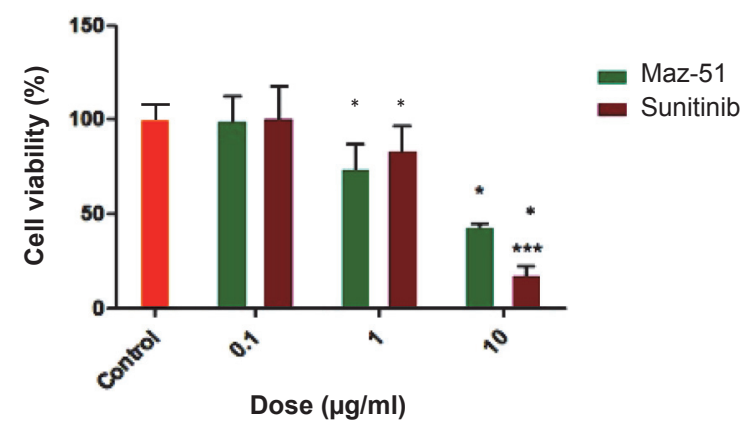

Fig. 1. The inhibition of vascular endothelial growth factor receptors with MAZ-51 and sunitinib decreases the viability of skin tumor cells, (A) the benign sEnd.2 and (B) malignant B16-F10 cells. ${ }^{*} P<0.05$ compared to the negative control; ${ }^{* * *} P<0.001$ compared to the negative control; \# $P<0.05$ compared to MAZ-51, values represent the mean \pm SD.

\section{Cell cycle analysis}

There was a significant increase in the percentage of sEnd.2 cells in the Sub-G1 phase following sunitinib treatment when compared to the negative control (Fig. 2A). Also, there were significantly fewer cells in the G1 phase (Fig. 2B) following treatment with sunitinib when compared to the negative control $(P<0.05)$. The effects of sunitinib were comparable to those of the positive control (Fig. 2B), which resulted in significantly fewer cells in the G1 phase $(P<0.001)$.

Cells treated with sunitinib were slightly increased in the G2/M phase when compared to those of the negative control (Fig. 2A and B). Sunitinib treatment further induced a slight but insignificant decrease in the percentage of sEnd.2 cells that were present in the S-phase.

\section{Scratch migration assay}

At 6 h, a slight closure of the artificial gap was visible, with no clear difference between the control and the sunitinib-treated cells (Fig. 3A). At 20 h, the migration of sEnd. 2 cells was evident in the control, while few migrated cells could be observed in the drug-treated cultures. After $24 \mathrm{~h}$ of treatment with sunitinib, there were still few migrated cells, while the control cells had migrated towards the 'wound' edge and the closure of the artificial gap was almost complete (Fig. 3A). Quantitative 

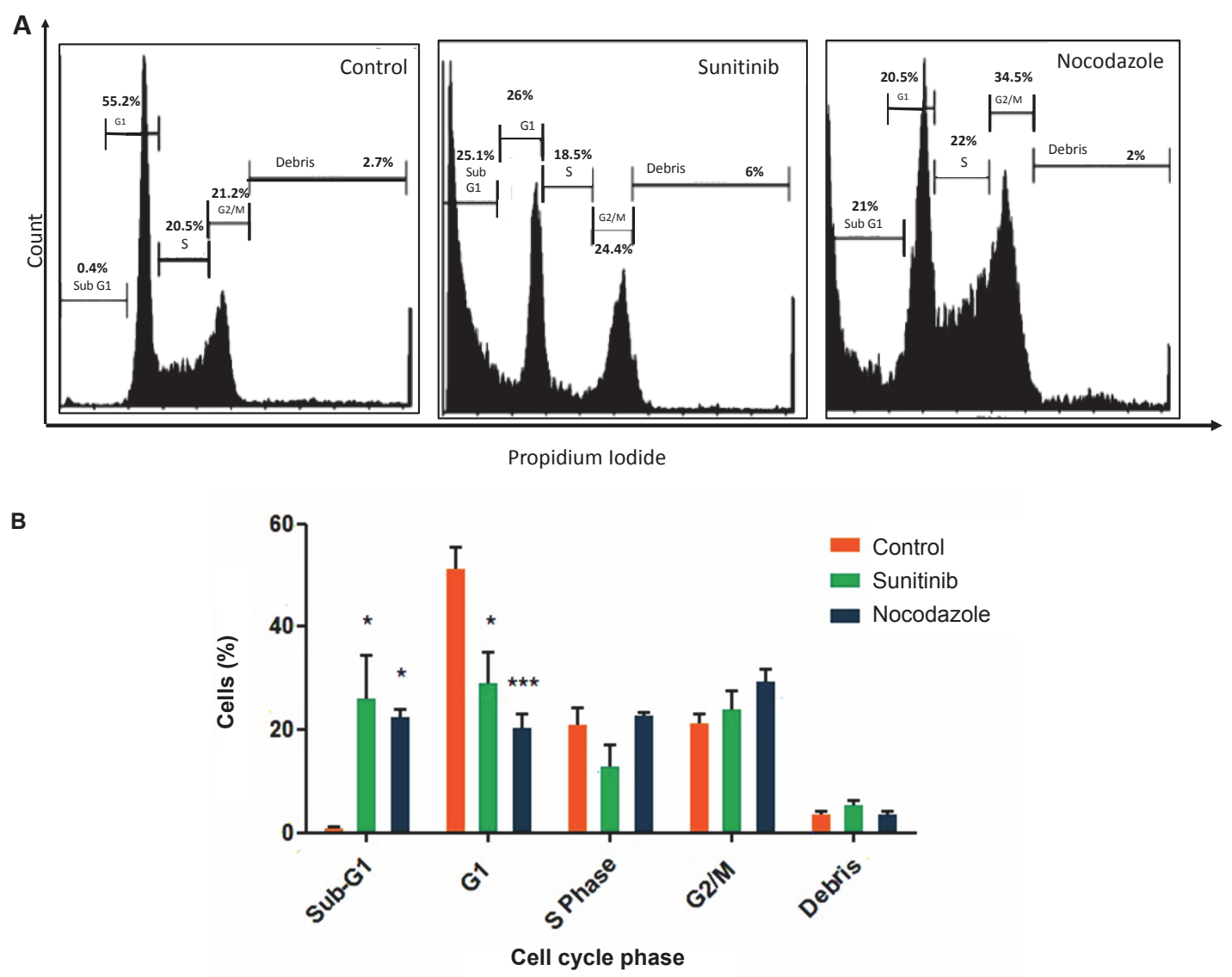

Fig. 2. Effects of sunitinib on cell cycle progression in sEnd.2 cells after 24-hour treatment. (A) Histograms indicating the distribution of cells in the various phases of the cell cycle (B) Percentage cell cycle distribution of sEnd.2 cells. Nocodazole was used as a positive control.

${ }^{*} P<0.05$ compared to the control; ${ }^{* * *} P<0.001$ compared to the control and values represent mean \pm SD.

analysis showed that sunitinib had an inhibitory effect on the migration of sEnd. 2 cells (Fig. 3B) $(P<0.05)$.

\section{Western blot}

Western blot analysis was conducted to determine the expression levels of proteins which regulate cell migration and angiogenesis (FAK, cadherin and paxillin). Results showed that sunitinib induced a decrease in the expression of paxillin and FAK (Fig. 4A, B, D), and that the decrease in the expression of these proteins was more pronounced at double the $\mathrm{IC}_{50}$ dose $(5.2 \mu \mathrm{g} / \mathrm{ml})$. The pan-cadherin antibody, which cross-reacts with various members of the cadherin family, namely, P-cadherin, N-cadherin, E-cadherin and R-cadherin, was employed to study the expression of cadherin. Sunitinib had no significant effect on the expression of cadherin at $\mathrm{IC}_{50}$ doses, $2.6 \mu \mathrm{g} / \mathrm{ml}$ (Fig. 4A, C). However, higher doses of sunitinib resulted in an decrease in the expression of cadherin. Furthermore, the expression of a proangiogenic cytokine which promotes tumour invasion and stimulates tumor angiogenesis, TGF- $\beta 1$, was investigated. Results also showed that TGF- $\beta 1$ expression was decreased in sunitinib treated cells compared to DMSO-treated cells (Fig. 5A, B).

\section{Reactive oxygen species assay}

The amount of ROS positive cells in the control was $4.37 \%$, while it was $7.55 \%$ following treatment with sunitinib (Fig. $6 \mathrm{~A}$, B). Although there was a slight increase in ROS+ cells in suniti- nib-treated cultures compared to the control, the drug did not induce any significant change $(P<0.05)$ in the ROS profile of the sEnd. 2 cells (Fig. 6A, B).

\section{Discussion}

The effects of VEGFR signaling blockade were studied on different facets pertaining to tumor progression such as growth, migration and adhesion/angiogenic protein levels. From the data, sunitinib proved to have the most potent effect on the viability of the two skin tumor cells, although its effects were more pronounced in hemangioma cells. At the doses used (0.1-10 $\mu \mathrm{g} / \mathrm{ml}$ or 3-30 $\mu \mathrm{M})$, MAZ-51 has been shown to inhibit the VEGF-C and VEGF-D autophosphorylation of VEGFR-3, with no effect on VEGFR-2 (Kirkin et al., 2001; 2004). The potency of sunitinib in inhibiting hemangioma cell growth may be due to the fact that at tested doses MAZ-51 inhibits VEGFR-3 while sunitinib blocks several tyrosine kinase receptors, namely VEGFRs, platelet derived growth factor receptors (PDGFRs) and c-KIT. Importantly, the overexpression of PDGFRs and c-KIT mutation have been associated with the development of haemangiomas (Ji et al., 2014). Furthermore, receptors targeted by both MAZ-51 and sunitinib are mainly expressed in endothelial cells (ECs), thus explaining the more pronounced effect of these drugs on these benign endothelial tumor cells than on melanoma cells. 
A
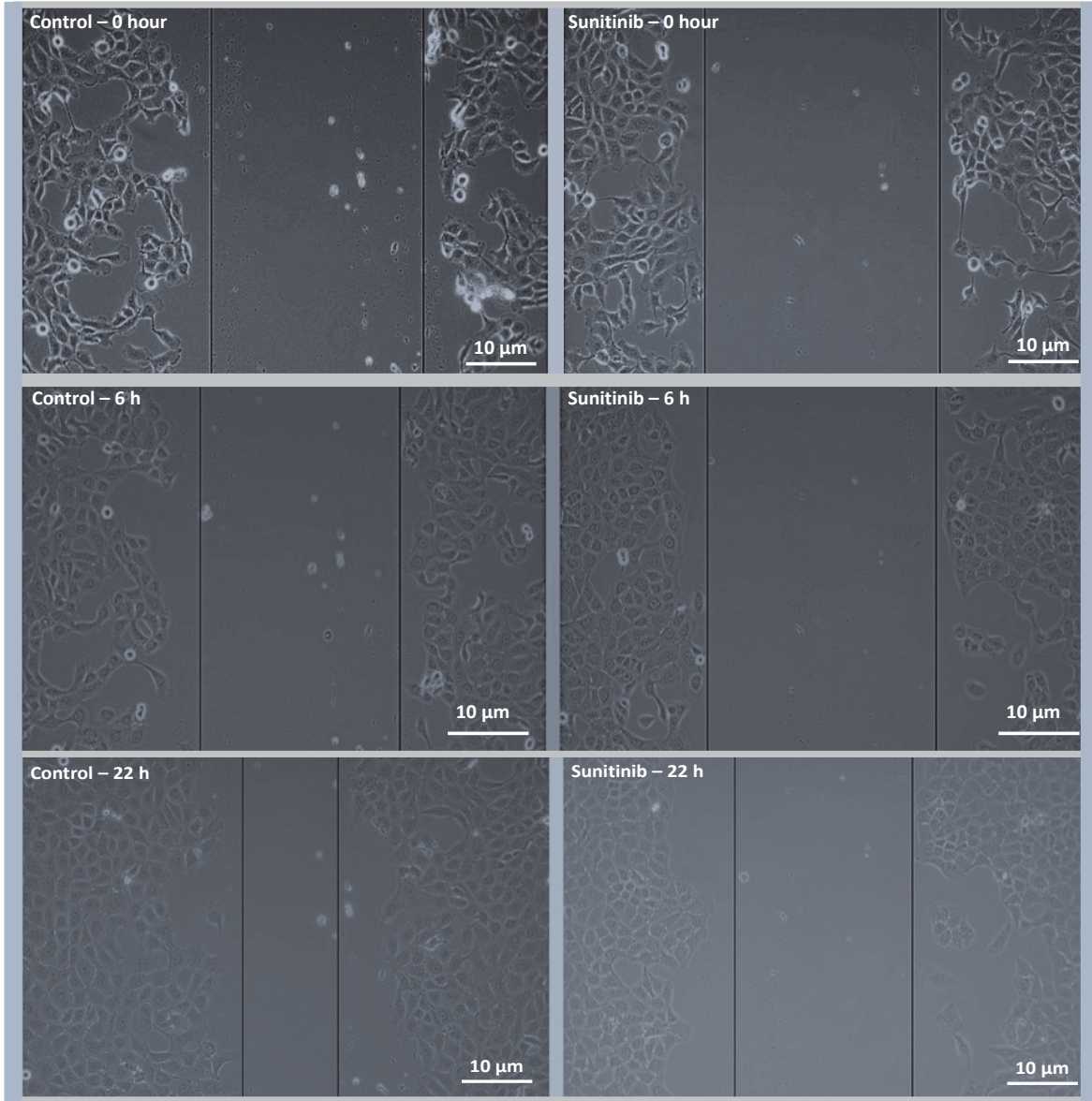

B

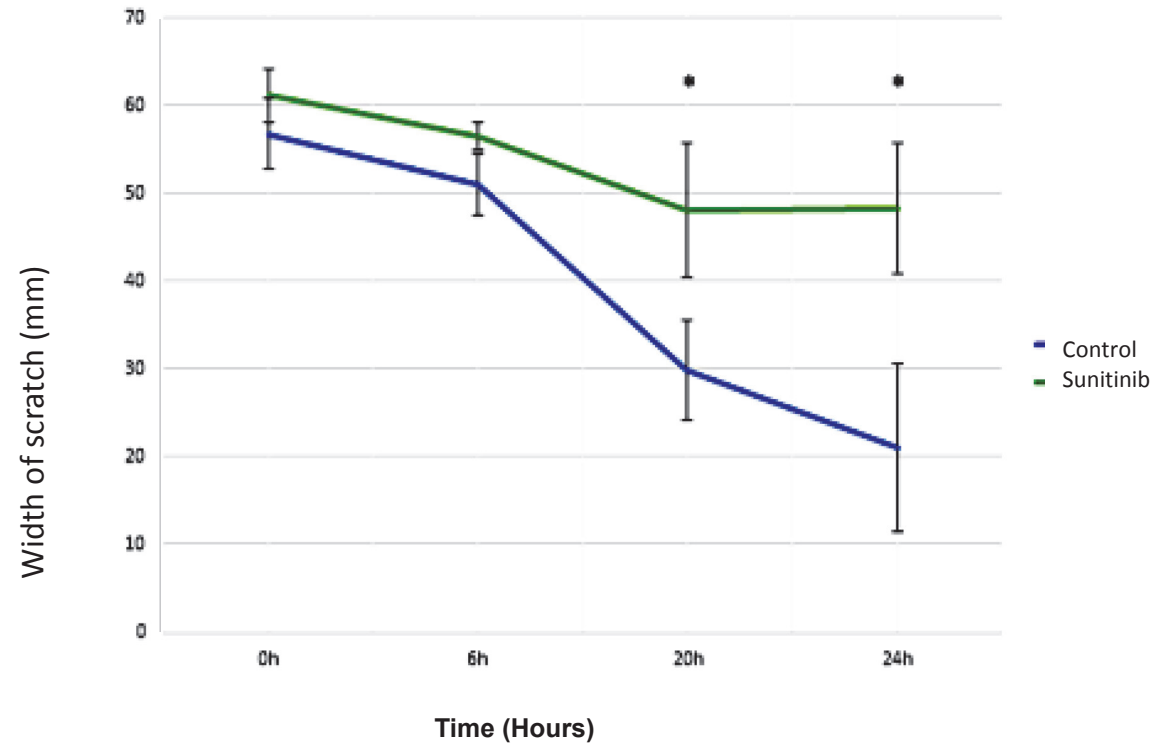

Fig. 3. Sunitinib inhibits cell motility. (A) Control and sunitinib $(2.6 \mu \mathrm{g} / \mathrm{ml})$ treated sEnd. 2 cells at different time-points. Lines indicate the edge of the monolayer. Bar $=10 \mu \mathrm{m}$. (B) Quantitative analysis of sEnd.2 cell migration. Sunitinib showed a potent inhibition of endothelial cell migration. ${ }^{*} p<0.05$ compared to the control, and values represent mean $\pm \mathrm{SD}$ of three separate experiments. 
A

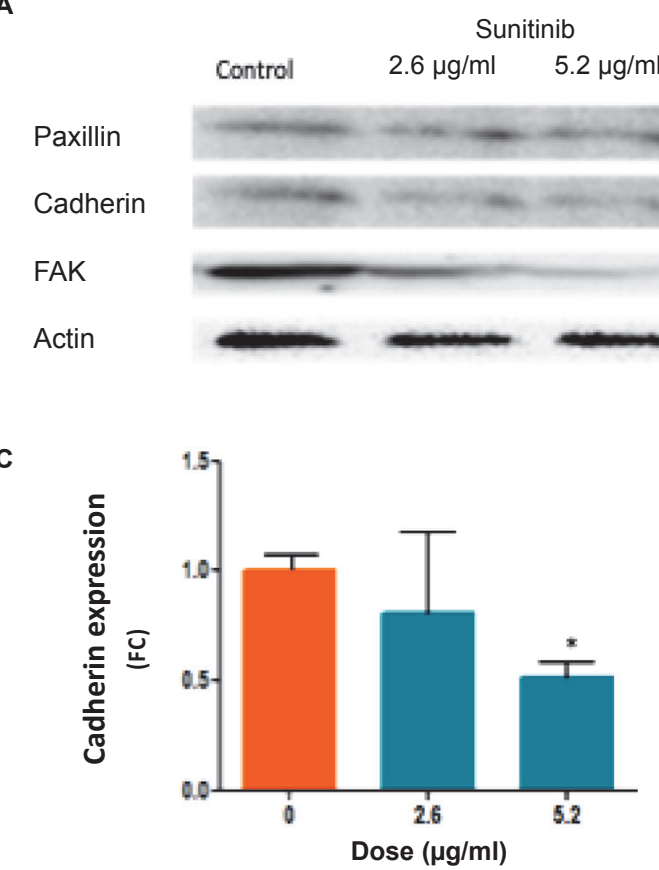

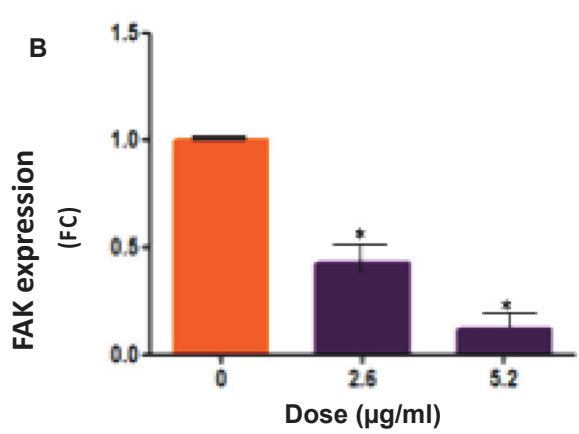

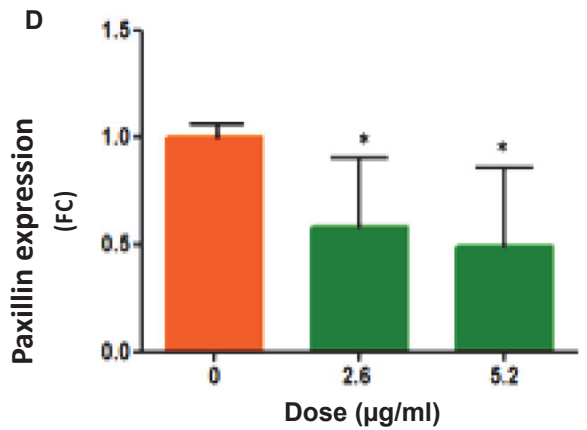

Fig. 4. Effects of sunitinib on the expression of adhesion proteins in sEnd. 2 cells. Actin was employed as a housekeeping protein. (A) Protein bands visualized in control and drug-treated cells, (B, C, D) Qualitative expression of FAK, Cadherin and Paxillin in control and Sunitinib-treated sEnd. 2 cells. Values represent the mean fold change (FC) protein expression normalized to actin \pm SD. * indicates $P<0.05$ compared to the DMSO control.

A

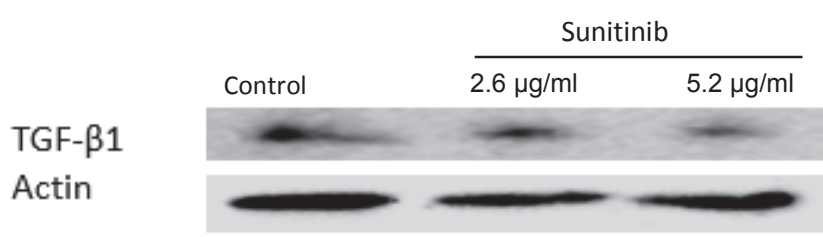

B

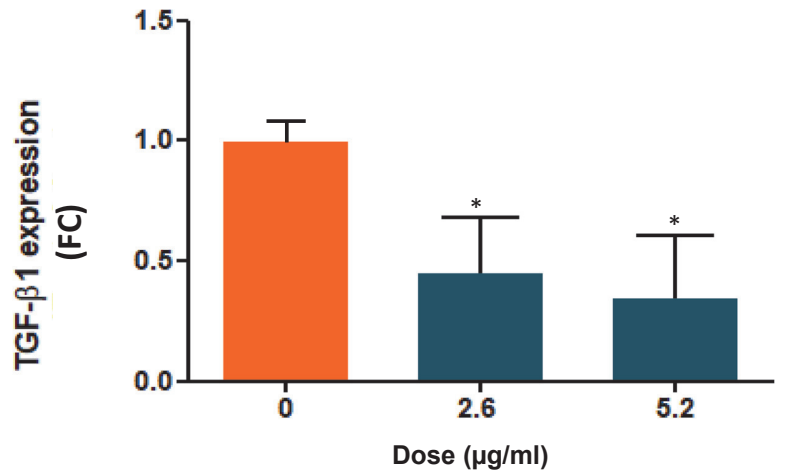

Fig. 5. Sunitinib treatment induces a decrease in the expression of transforming growth factor- $\beta 1$ (TGF- $\beta 1$ ) in sEnd. 2 cells. Actin was employed as a housekeeping protein. (A) Protein bands visualized in control and drug-treated cells, (B) Qualitative expression of TGF- $\beta 1$ in control and sunitinib-treated sEnd. 2 cells. Values represent the mean fold change $(\mathrm{FC})$ protein expression normalized to actin $\pm \mathrm{SD}$. ${ }^{*} P<0.05$ compared to the DMSO control. 
A

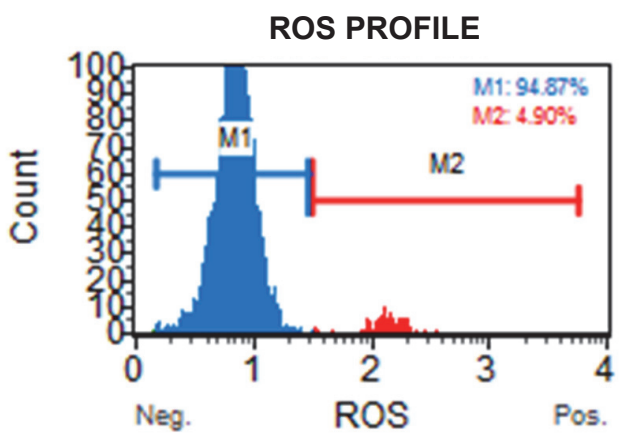

B

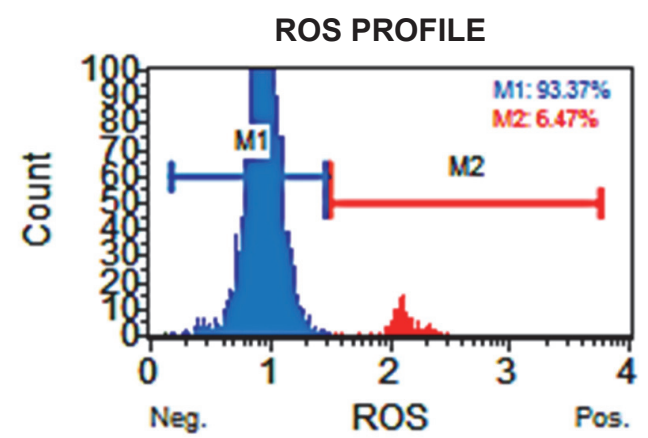

C

ROS Profile of sEnd.2 cells after $24 \mathrm{~h}$ treatment

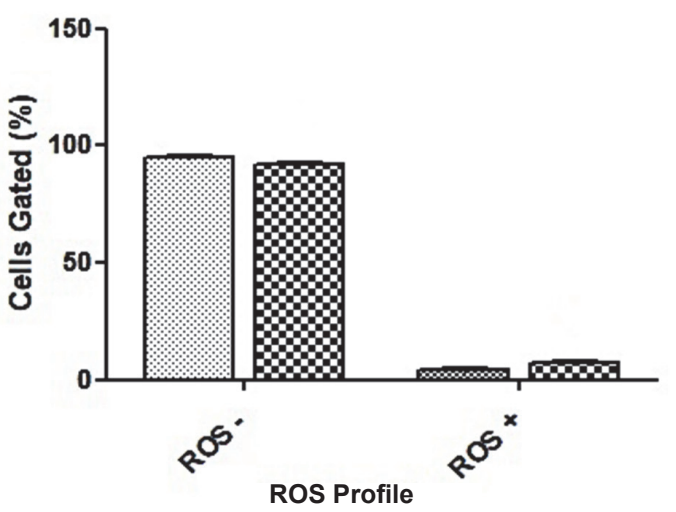

Fig. 6. Effects of sunitinib on reactive oxygen species production by sEnd.2 cells. Representative graphs showing ROS profiles of (A) Control and (B) Sunitinib $(2.6 \mu \mathrm{g} / \mathrm{ml})$-treated sEnd. 2 cells. (C) ROS profile of sEnd. 2 cells after 24-hour treatment with Sunitinib $2.6 \mu \mathrm{g} / \mathrm{ml}$. The mean percentage of ROS positive cells in the control was 4.37, while it was 7.55 following treatment with sunitinib. Values represent the mean of three separate experiments $\pm S D$; there was no significant difference at $P<0.05$ between control and sunitinib-treated cells.

The decreased sEnd.2 cell viability observed following sunitinib treatment correlated with an increase in the percentage of these cells in the Sub-G1 phase $(p<0.05)$. Noteworthy is that the Sub-G1 phase is associated with cell death (Kang et al., 2020). In a study by Di Desidero et al. (2013), sunitinib inhibited the proliferation of human dermal microvascular endothelial cells (HMVEC-d) and induced an increase in the Sub-G1 cell population. Similarly, in another study sunitinib induced a significant increase in the percentage of human umbilical vein endothelial cells (HUVECs) in the Sub-G1 phase (Brossa et al., 2015). These studies also showed that sunitinib caused apoptosis in ECs (Brossa et al., 2015). It is thus possible that sunitinib may inhibit the growth of sEnd. 2 cells partly by inducing cell death.

Further evaluation of the effects of sunitinib on the migration of hemangioma cells showed changes in the width of the wound from $6 \mathrm{~h}$, although quantitative analysis showed that the inhibition of sEnd. 2 cell motility was more pronounced from $20 \mathrm{~h}$. In a study investigating the effect of sunitinib on the migration of non-transformed HUVECs employing the same assay over $24 \mathrm{~h}$, sunitinib inhibited cell migration after $9 \mathrm{~h}$ (Moravcik et al., 2016). In another separate study sunitinib inhibited the migration of prostate tumor derived ECs after 4-6 h of treatment (Pla et al., 2014). Furthermore, sunitinib has been shown to inhibit the migration of human benign and malignant meningioma cells as well as ECs and to inhibit angiogenesis (Andrae et al., 2012; Brossa et al., 2015; Grunewald et al., 2019). Taken together, the reported studies as well as the current study reveal that sunitinib inhibits the migration of tumor endothelial cells. Furthermore, previous studies reveal that sunitinib's anti-migratory effects in tumor-derived ECs are evident after shorter periods of exposure than in normal ECs (Andrae et al., 2012; Brossa et al., 2015; Grunewald et al., 2019; Pla et al., 2014). This may imply that ECs derived from tumor vessels such as hemangioma cells are more susceptible to the effects of sunitinib than normal ECs.

Sunitinib induced a decrease in the expression of FAK, an adhesion protein that is actively involved in several pathways that modulate cell migration and angiogenesis. In our laboratory we have shown that the blocking of FAK with PF573,228 in sEnd. 2 cells led to reduced cell migration and invasion (Mabeta, 2016). In another study, FAK inhibitors induced a decrease in EC migration, similar to the results of the present study (Cabrita et al., 2011). In a separate study, FAK inhibition in glioblastoma xenografts reduced tumor microvascular density (Roberts et al., 2008). In contrast to FAK, there was no significant change in the expression of cadherin, a protein that modulates calcium-dependent cell surface adhesion. However, a reduced expression of the protein was observed when cells were exposed to double the IC50 dose $(5.2 \mu \mathrm{g} / \mathrm{ml})$.

On the other hand, the expression of paxillin, an adapter adhesion protein downstream of FAK signaling, was also decreased in sunitinib-treated cells. Paxillin plays a crucial role in adhesion by recruiting structural and signaling molecules that regulate cell migration. Upon integrin engagement with the extracellular matrix (ECM), paxillin is activated through phos- 
phorylation at Tyr31, Tyr118, Ser188, and Ser190, resulting in the promotion of cell movement (López-Colomé et al., 2017). This further implies that by blocking VEGFR-2 activation, sunitinib could have led to a decrease in FAK and paxillin expression and therefore, reduced the migration of sEnd. 2 cells as observed in this study. Of note is that the ligand for VEGFR-2, VEGF-A, is involved in the activation of FAK and the induction of angiogenesis (Abedi and Zachary, 1997; Cabrita et al., 2011; Koch and Claesson-Welsh, 2012). Thus, our findings indicate that the drug-induced decrease in FAK expression may lead to an inhibition of hemangioma cell migration and possibly the associated angiogenesis. Indeed, our findings show that sunitinib induced a decrease in the expression of a cytokine that regulates angiogenesis, TGF- $\beta 1$, which is the TGF- $\beta$ isoform also commonly implicated in tumorigenesis.

The growth factor acts in the vascular microenvironment by increasing the expression of matrix metalloproteinases (MMPs), ultimately leading to the degradation of the ECM and an increase in cell motility and neovascularization (Akhurst and Derynck, 2001; Drabsch and ten Dijke, 2012; Padua and Massagué, 2009).

In a study comparing the effects of sunitinib and another RTK inhibitor, sorafenib on prostate tumor derived ECs, sunitinib proved to be superior with regards to its inhibitory effects on cell proliferation, survival and motility (Pla et al., 2014). Sunitinib has been incorporated in various drug combination studies in preclinical models and in clinical trials, with promising results (Bianchini et al., 2019; Kuang et al., 2018; Nikolaou et al., 2012; Yeramian et al., 2012). It is plausible that sunitinib could be incorporated in combination treatments targeting receptors expressed by hemangioma cells, although studies are required to investigate combination approaches.

Reactive oxygen species contribute to angiogenesis by stimulating VEGF-A production. Exploratory studies were thus conducted to evaluate the effects of sunitinib on ROS. There was no significant alteration in the number of ROS+ cells following sunitinib treatment when compared to the control at doses that inhibited both cell growth and migration. This observation is of significance since ROS, which promotes angiogenesis, is also a marker of endothelial dysfunction (ED) and is linked to cardiovascular disorders such as atherosclerosis and hypertension (Xia et al., 2007).

It is worth noting that cardiotoxicity is a major side effect of sunitinib treatment and several other drugs that target the VEGF-VEGFR pathway (Jain et al., 2006; León-Mateos et al., 2015). Recently, we observed that at the same doses, sunitinib did not increase the levels of nitric oxide (NO) and angiotensin II, both important molecules in vascular homeostasis and contributors to ED. Thus, the possibility of employing sunitinib to target multiple receptors involved in tumor growth at doses that may not induce ED provides an opportunity for hemangioma treatment.

\section{Conclusions}

This study showed that VEGFR signaling blockade with sunitinib was the most effective in inhibiting hemangioma cell growth. The drug also inhibited cell migration, an important step in the progression of the tumor. In addition, there was a decrease in the expression of FAK, paxillin and TGF- $\beta 1$, important proteins in EC migration and angiogenesis. This study further revealed that sunitinib does not elicit significant changes in ROS production at $\mathrm{IC}_{50}$ doses $(2.6 \mu \mathrm{g} / \mathrm{ml})$. This is a desirable outcome as oxidative stress supports tumor angiogenesis and is also linked to endothelial dysfunction. Therefore, blocking VEGFR signaling with a multi-targeting RTKI such as sunitinib may be effective in the treatment of hemangiomas.

\section{Conflict of interests}

The authors declare no conflict of interests.

\section{Acknowledgements}

The authors acknowledge funding support from the National Research Foundation (Dr. Mabeta-Project 114403) and the University of Pretoria. We thank Prof. P. Becker for the study design and for statistical support.

\section{Author contributions}

WS conducted experiments; PM assisted with the analysis of results and prepared the manuscript.

\section{References}

Abedi H, Zachary I (1997). Vascular endothelial growth factor stimulates tyrosine phosphorylation and recruitment to new focal adhesions of focal adhesion kinase and paxillin in endothelial cells. J Biol Chem 272(24): 15442-15451. DOI: 10.1074/ jbc.272.24.15442.

Akhurst RJ, Derynck R (2001). TGF- $\beta$ signaling in cancer - a doubleedged sword. Trends Cell Biol 11(11): S44-S51. DOI: 10.1016/ S0962-8924(01)02130-4.

Andrae N, Kirches E, Hartig R, Haase D, Keilhoff G, Kalinski T, Mawrin C (2012). Sunitinib targets PDGF-receptor and Flt3 and reduces survival and migration of human meningioma cells. Eur J Cancer 48(12): 1831-1841. DOI: 10.1016/j.ejca.2012.01.032.

Bianchini F, Portioli E, Ferlenghi F, Vacondio F, Andreucci E, Biagioni A, et al. (2019). Cell-targeted c(AmpRGD)-sunitinib molecular conjugates impair tumor growth of melanoma. Cancer Lett 446: 25-37. DOI: 10.1016/j.canlet.2018.12.021.

Braconi C, Bracci R, Cellerino R (2008). Molecular targets in gastrointestinal stromal tumors (GIST) therapy. Curr Cancer Drug Targets 8(5): 359-366. DOI: 10.2174/156800908785133169.

Brossa A, Grange C, Mancuso L, Annaratone L, Satolli MA, Mazzone M, et al. (2015). Sunitinib but not VEGF blockade inhibits cancer stem cell endothelial differentiation. Oncotarget 6(13): 11295-11309. DOI: 10.18632/oncotarget.3123.

Cabrita MA, Jones LM, Quizi JL, Sabourin LA, McKay BC, Addison CL (2011). Focal adhesion kinase inhibitors are potent anti-angiogenic agents. Mol Oncol 5(6): 517-526. DOI: 10.1016/j. molonc.2011.10.004.

Chim H, Armijo BS, Miller E, Gliniak C, Serret MA, Gosain AK (2012). Propranolol induces regression of hemangioma cells through HIF-1 $\alpha$-mediated inhibition of VEGF-A. Ann Surg 256(1): 146-156. DOI: 10.1097/SLA.0b013e318254ce7a.

Di Desidero T, Fioravanti A, Orlandi P, Canu B, Giannini R, Borrelli N, Bocci G (2013). Antiproliferative and proapoptotic activity of sunitinib on endothelial and anaplastic thyroid cancer cells via inhibition of Akt and ERK1/2 phosphorylation and by down-regulation of Cyclin-D1. J Clin Endocrinol Metab 98(9): E1465-E1473. DOI: 10.1210/jc.2013-1364.

Drabsch Y, ten Dijke P (2012). TGF- $\beta$ signalling and its role in cancer progression and metastasis. Cancer Metastasis Rev 31(3): 553-568. DOI: 10.1007/s10555-012-9375-7.

Feoktistova M, Geserick P, Leverkus M (2016). Crystal violet assay for determining viability of cultured cells. Cold Spring Harbor Protocols 2016(4): pdb-rot087379. DOI: 10.1101/pdb. prot087379.

Grunewald ZI, Ghiarone T, Quinones-Morales M, Ramirez-Perez F, Martinez-Lemus L, Padilla J (2019). Activation of protein kinase C impairs endothelium-dependent vasorelaxation in isolated human omental resistance arteries. FASEB J 33(Suppl. 1): 685.616685.616. DOI: 10.1096/fasebj.2019.33.1_supplement.685.16. 
Haas B, Weber-Lassalle K, Frötschl R, Eckstein N (2016). Is sunitinib a narrow therapeutic index drug? - A systematic review and in vitro toxicology-analysis of Sunitinib vs. Imatinib in cells from different tissues. Regul Toxicol Pharmacol 77(2016): 25-34. DOI: 10.1016/j.yrtph.2016.02.010.

Ignarro LJ, Byrns RE, Buga GM, Wood KS (1987). Endotheliumderived relaxing factor from pulmonary artery and vein possesses pharmacologic and chemical properties identical to those of nitric oxide radical. Circ Res 61(6): 866-879. DOI: 10.1161/01. res.61.6.866.

Ionescu G, Mabeta P, Dippenaar N, Muir T, Fourie P, Shelver G (2008). Bleomycin plasma spill-over levels in paediatric patients undergoing intralesional injection for the treatment of hemangiomas. S Afr Med J 98(7): 539-540.

Jain RK, Duda DG, Clark JW, Loeffler JS (2006). Lessons from phase III clinical trials on anti-VEGF therapy for cancer. Nat Rev Clin Oncol 3(1): 24-40. DOI: 10.1038/ncponc0403.

Ji Y, Chen S, Li K, Li L, Xu C, Xiang B (2014). Signaling pathways in the development of infantile hemangioma. J Hematol Oncol 7(1): 13. DOI: 10.1186/1756-8722-7-13.

Joseph JJ, Sangeetha D, Gomathi T (2016). Sunitinib loaded chitosan nanoparticles formulation and its evaluation. Int J Biol Macromol 82(2016): 952-958. DOI: 10.1016/j.ijbiomac.2015.10.079.

Kang FC, Chen YC, Wang SC, So EC, Huang BM (2020). Propofol induces apoptosis by activating caspases and the MAPK pathways, and inhibiting the Akt pathway in TM3 mouse Leydig stem/ progenitor cells. Int J Molec Med 46(1): 439-448. DOI: 10.3892/ ijmm.2020.4584.

Kirkin V, Mazitschek R, Krishnan J, Steffen A, Waltenberger J, Pepper MS, et al. (2001). Characterization of indolinones which preferentially inhibit VEGF-C- and VEGF-D-induced activa- tion of VEGFR-3 rather than VEGFR-2. Eur J Biochem 268: 5530-5540. DOI: 10.1046/j.1432-1033.2001.02476.x.

Kirkin V, Thiele W, Baumann P, Mazitschek R, Rohde K, Fellbrich G, et al. (2004). MAZ51, an indolinone that inhibits endothelial cell and tumor cell growth in vitro, suppresses tumor growth in vivo. Int J Cancer 112(6): 986-993. DOI: 10.1002/ijc.20509.

Koch S, Claesson-Welsh L (2012). Signal transduction by vascular endothelial growth factor receptors. Cold Spring Harb Perspect Med 2(7): a006502. DOI: 10.1101/cshperspect.a006502.

Kuang X, Qi M, Peng C, Zhou C, Su J, Zeng W, Chen X (2018). Propranolol enhanced the anti-tumor effect of sunitinib by inhibiting proliferation and inducing G0/G1/S phase arrest in malignant melanoma. Oncotarget 9(1): 802-811. DOI: 10.18632/ oncotarget.22696.

León-Mateos L, Mosquera J, Antón Aparicio L (2015). Treatment of sunitinib-induced hypertension in solid tumor by nitric oxide donors. Redox Biol 6: 421-425. DOI: 10.1016/j. redox.2015.09.007.

Liu L, Kakiuchi-Kiyota S, Arnold LL, Johansson SL, Wert D, Cohen SM (2013). Pathogenesis of human hemangiosarcomas and hemangiomas. Hum Pathol 44(10): 2302-2311. DOI: 10.1016/j. humpath.2013.05.012.

López-Colomé AM, Lee-Rivera I, Benavides-Hidalgo R, López E (2017). Paxillin: a crossroad in pathological cell migration. J Hematol Oncol 10(1): 50. DOI: 10.1186/s13045-017-0418-y.

Mabeta P (2016). PF573,228 inhibits vascular tumor cell growth, migration as well as angiogenesis, induces apoptosis and abrogates PRAS40 and S6RP phosphorylation. Acta Pharm 66(3): 399-410. DOI: $10.1515 /$ acph-2016-0031.

Mabeta P (2018). Oncosuppressors and oncogenes: Role in haemangioma genesis and potential for therapeutic targeting. Int J Mol Sci 19(4). DOI: 10.3390/ijms19041192.

Mabeta P, Pepper MS (2009). A comparative study on the antiangiogenic effects of DNA-damaging and cytoskeletal-disrupting agents. Angiogenesis 12(1): 81-90. DOI: 10.1007/s10456-0099134-8.

Mabeta P, Pepper MS (2011). Hemangiomas-current therapeutic strategies. International Journal of Developmental Biology 55(4-5): 431-437. DOI: 10.1387/ijdb.103221pm.

Mabeta P, Pepper MS (2012). Inhibition of hemangioma development in a syngeneic mouse model correlates with bcl-2 suppression and the inhibition of Akt kinase activity. Angiogenesis 15(1): 131-139. DOI: 10.1007/s10456-011-9248-7.

Mabeta P, Pepper MS (2015). Altered expression of platelet factor 4 and basic fibroblast growth factor correlates with the inhibition of tumor growth in mice. Biomed Pharmacother 69: 186-190. DOI: 10.1016/j.biopha.2014.11.018.

Moravcik R, Stebelova K, Bohac A, Zeman M (2016). Inhibition of VEGF mediated post receptor signalling pathways by recently developed tyrosine kinase inhibitor in comparison with sunitinib. Gen Physiol Biophys 35(4): 511-514. DOI: 10.4149/gpb_2015055.

Nikolaou VA, Stratigos AJ, Flaherty KT, Tsao H (2012). Melanoma: new insights and new therapies. J Invest Dermatol 132(3, Part 2): 854-863. DOI: 10.1038/jid.2011.421.

Padua D, Massagué J (2009). Roles of TGF $\beta$ in metastasis. Cell Res 19(1): 89-102. DOI: 10.1038/cr.2008.316.

Park M, Jung HL, Shim YJ, Kim HS, Yoon HS, Park SK, et al. (2020). Serum cytokine profiles in infants with infantile hemangiomas on oral propranolol treatment: VEGF and bFGF, potential biomarkers predicting clinical outcomes. Pediatr Res 88(5): 749-755. DOI: $10.1038 / s 41390-020-0862-1$.

Pla FA, Brossa A, Bernardini M, Genova T, Grolez G, Villers A, Bussolati B (2014). Differential sensitivity of prostate tumor derived endothelial cells to sorafenib and sunitinib. BMC Cancer, 14(1): 939. DOI: 10.1186/1471-2407-14-939.

Podar K, C Anderson K (2011). Emerging therapies targeting tumor vasculature in multiple myeloma and other hematologic and solid malignancies. Curr Cancer Drug Targets 11(9): 1005-1024. DOI: $10.2174 / 156800911798073113$.

Quintieri L, Selmy M, Indraccolo S (2014). Metabolic effects of antiangiogenic drugs in tumors: Therapeutic implications. Biochem Pharmacol 89(2): 162-170. DOI: 10.1016/j. bcp.2014.02.018.

Roberts WG, Ung E, Whalen P, Cooper B, Hulford C, Autry C, Vajdos F (2008). Antitumor activity and pharmacology of a selective focal adhesion kinase inhibitor, PF-562,271. Cancer Res 68(6): 1935-1944. DOI: 10.1158/0008-5472.can-07-5155.

Tugues S, Koch S, Gualandi L, Li X, Claesson-Welsh L (2011). Vascular endothelial growth factors and receptors: Anti-angiogenic therapy in the treatment of cancer. Mol Aspects Med 32(2): 88-111. DOI: 10.1016/j.mam.2011.04.004.

Walter JW, North PE, Waner M, Mizeracki A, Blei F, Walker JW, et al. (2002). Somatic mutation of vascular endothelial growth factor receptors in juvenile hemangioma. Genes Chromosomes Cancer 33(3): 295-303. DOI: 10.1002/gcc.10028.

Weis SM, Cheresh DA (2011). Tumor angiogenesis: Molecular pathways and therapeutic targets. Nat Med 17(11) 1359-1370. DOI: $10.1038 / \mathrm{nm} .2537$.

Xia C, Meng Q, Liu L-Z, Rojanasakul Y, Wang X-R, Jiang B-H (2007). Reactive oxygen species regulate angiogenesis and tumor growth through vascular endothelial growth factor. Cancer Res 67(22): 10823-10830. DOI: 10.1158/0008-5472.CAN-07-0783.

Yeramian A, Sorolla A, Velasco A, Santacana M, Dolcet X, Valls J, Martí RM (2012). Inhibition of activated receptor tyrosine kinases by Sunitinib induces growth arrest and sensitizes melanoma cells to Bortezomib by blocking Akt pathway. Int J Cancer 130(4): 967-978. DOI: 10.1002/ijc.26096. 